\title{
THE EFFECT OF A SINGLE ORAL DOSE OF THE CARBONIC ANHYDRASE INHIBITOR, ACETAZOLEAMIDE, IN RENAL DISEASE
}

\author{
By MICHAEL KAYE 1 \\ (From McGill University Clinic, Royal Victoria Hospital, Montreal, Canada)
}

(Submitted for publication July 21, 1954 ; accepted October 20, 1954)

The carbonic anhydrase inhibitor acetazoleamide, (2-acetylamino-1,3,4-thiadazole-5 sulfonamide, 6063 , Diamox ${ }^{\circledR}$ ), is believed to decrease the exchange of hydrogen for sodium ions in the renal tubule (1). Alkalinization of the urine with sodium, potassium, and bicarbonate diuresis is found after its administration, both in normal people and in patients with cardiac failure (2). Except for the report by Metcoff, James, and Gordillo in nephrosis (3), no data are available concerning the effect of acetazoleamide in primary renal disease. This investigation was undertaken to see if the effect in patients with renal disease was the same as in normal people, and to evaluate any possible therapeutic benefit from the use of the drug.

The action of acetazoleamide is believed to be limited to the carbonic anhydrase enzyme system, and this suggested that it could be used to determine the presence of functioning renal carbonic anhydrase. The occurrence of the customary urine changes after administration of acetazoleamide would then indicate the presence of functioning carbonic anhydrase in the kidney.

\section{MATERIAL AND METHODS}

The subjects used for this investigation included four healthy young males and fifteen patients who were selected because of the presence of severe renal disease. Each patient's clinical status was steady at the time of study. None had diarrhea or vomiting. The individual diagnoses are shown in Table I, with clinical data and details of tests obtained within a few days of acetazoleamide administration, in the Appendix. All subjects were in bed overnight and were in a basal post-absorptive state, remaining recumbent throughout the procedure. An indwelling urethral catheter containing multiple holes in the tip was inserted into the bladder at least two and one-half hours before the start of the first collection period in all subjects, except in the case of the normal males M. K. and J. B. who voided spontaneously under oil.

${ }^{1}$ Hosmer Teaching Fellow in Medicine, McGill University.
Exposure of the urine to air was avoided in all. In the first eleven cases studied, the catheter was connected by a short length of rubber tubing and the urine allowed to drain into a container under a layer of mineral oil. In the last six cases, urine was withdrawn directly into oiled 50 cc. syringes. Specimens were kept on ice until analysed the same morning. Water, $120 \mathrm{cc}$. to $300 \mathrm{cc}$. depending on body weight, was taken orally at 5 a.m. and thereafter hourly until 1 p.m. The first collection period started at 8:30 a.m., each lasted one hour, the bladder being emptied by firm suprapubic pressure at the end. After two control periods, approximately $10 \mathrm{mg}$. per kg. of acetazoleamide ${ }^{2}$ were given orally, and three more collection periods obtained, the last one ending at 1:30 p.m. The entire procedure was tolerated without discomfort. Blood for non-protein nitrogen and bicarbonate was taken during the control period.

The range of urine specific gravity was determined from multiple random analyses and in addition either a Mosenthal, or a concentration and dilution test. The excretion of phenolsulfonphthalein following intravenous injection was determined in the usual manner. Urine was collected by catheterization.

The chemical methods employed were for serum nonprotein nitrogen, Evelyn's modification of Folin-Wu; sodium and potassium by internal standard flame photometry; bicarbonate in plasma and urine by the volumetric method of Van Slyke and Cullen (4) after equilibrating with $\mathrm{CO}_{2}$ at a tension of $40 \mathrm{~mm}$. $\mathrm{Hg}$. Although this technique is not ideal, the difference between the bicarbonate estimated at a $\mathrm{pCO}_{2}$ of $40 \mathrm{~mm}$. $\mathrm{Hg}$ and that actually existing is small, and does not influence these results. Blood $\mathrm{pH}$ was not determined, but it is believed that under the conditions in which these patients were studied, a low serum bicarbonate indicated the presence of metabolic acidosis. Urine $\mathrm{pH}$ was determined at room temperature using a Beckman meter and a 290-31 anaerobic electrode. Chloride was determined by the technique of Wilson and Ball (5); phosphorus by that of Fiske and Subbarow (6). Titratable acidity was determined by the method of Henderson and Palmer (7), the end point being checked using a $\mathrm{pH}$ meter. Ammonia nitrogen was determined by the continuous aeration technique (8).

2 Supplied through the courtesy of Dr. J. D. Gallagher, Lederle Laboratories Division, American Cyanamid Company. 


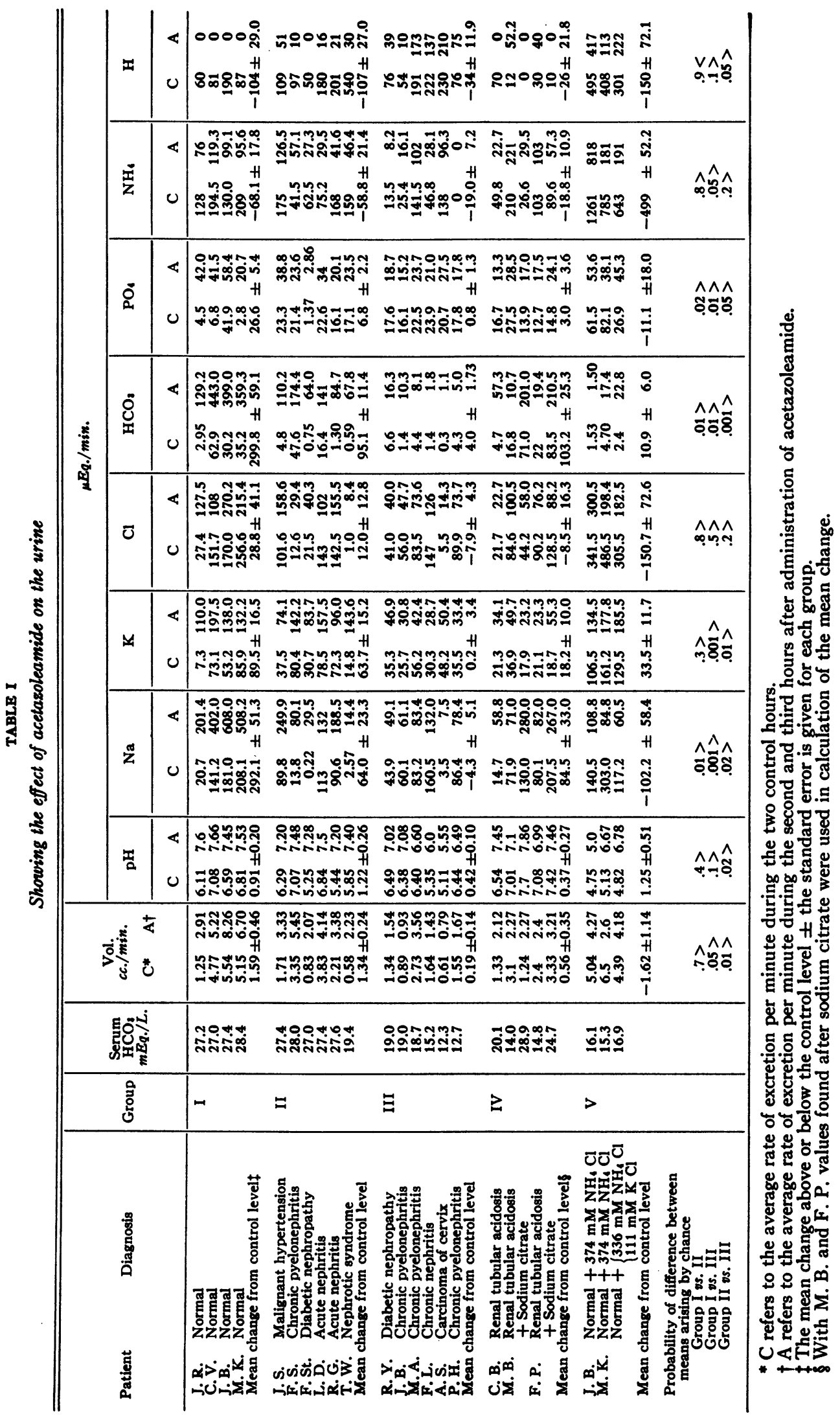




\section{RESULTS}

For comparison of the findings, the rates of excretion per minute found during the two control hours have been averaged and compared to the average values found during the second and third hours after giving acetazoleamide. The data are shown in Table I and presented graphically in Figure 1.

\section{Group I-Normal subjects}

The response to the administration of acetazoleamide in the four normal subjects was similar to that described previously in both man (2) and the dog (9), consisting of a moderate increase in urine volume and a rise in urine $\mathrm{pH}$ over 7.4 with diminution in titratable acid and ammonia. There was a marked increase in sodium and bicarbonate excretion with a smaller rise in potassium loss. Any change in chloride loss was inconstant but phosphate excretion increased slightly.

\section{Group II-Renal disease without acidosis}

There were six patients in this group all of whom had normal plasma bicarbonate levels except for T. W., in whom it was $19.4 \mathrm{mEq}$. per L. This was associated with vomiting before admission and the presence of a large empyema. All patients showed a response to the drug. There was, however, a significant decrease in sodium and bicarbonate loss as compared with Group I, with potassium tending to be the major cation accompanying the increase in excreted bicarbonate. This was most marked in the patients with the smallest increments in sodium excretion. Changes in urine volume, $\mathrm{pH}$, titratable acid and ammonia were similar in the two groups.

\section{Group III-Renal disease with acidosis}

The six patients in this group all had metabolic acidosis caused by renal insufficiency, with plasma bicarbonates $19 \mathrm{mEq}$. per L. or less. The urinary

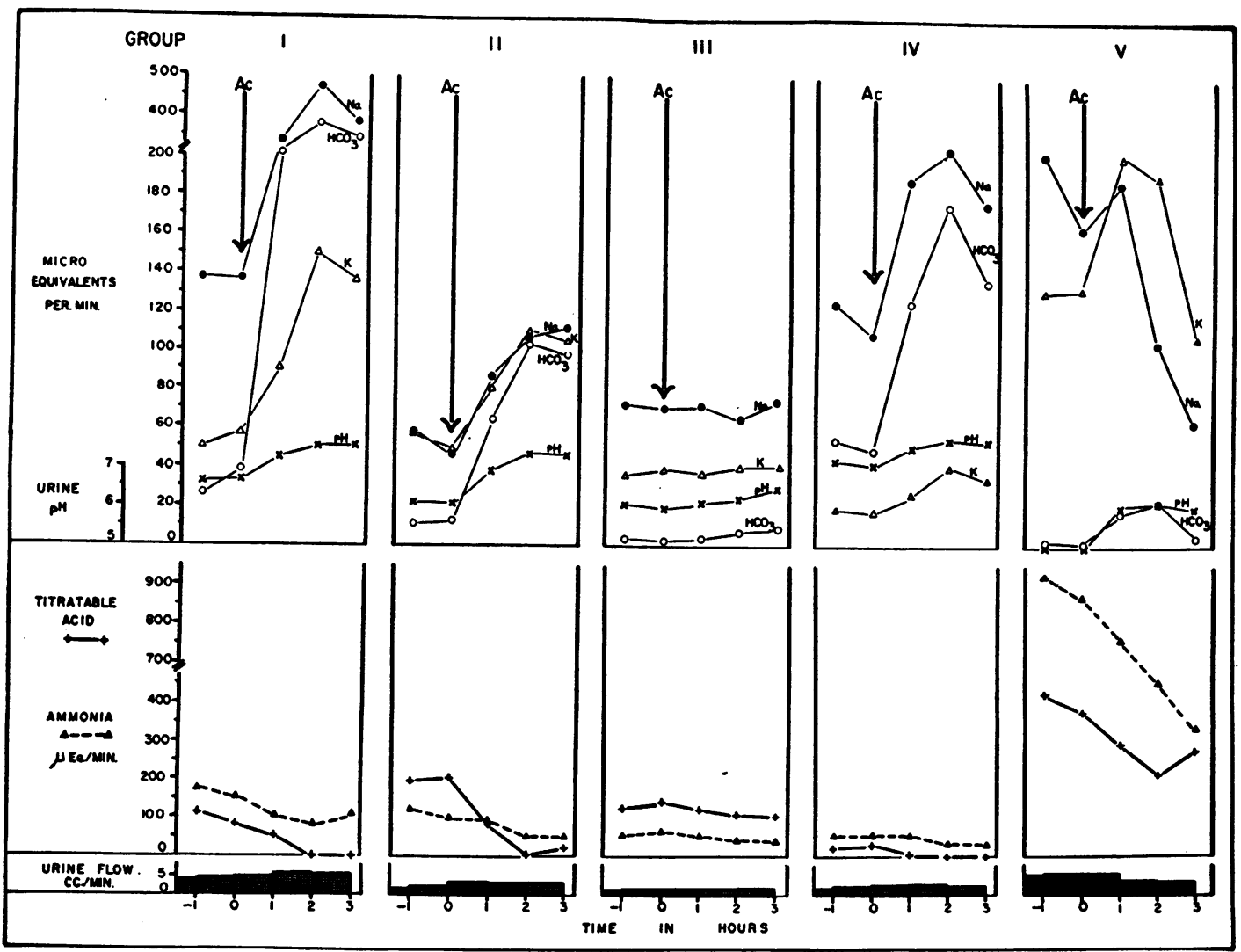

Fig. 1. Showing the Mean Rates of Excretion in each Group before and after Acetazoleamide 
changes after acetazoleamide were minimal or absent completely.

\section{Group IV-Renal tubular acidosis}

Three patients with this syndrome were studied. C. B. had a plasma bicarbonate level of 20.1 $\mathrm{mEq}$. per L. and he showed the usual urinary changes after acetazoleamide. M. B. and F. P. with plasma bicarbonates of $14.0 \mathrm{mEq}$. per $\mathrm{L}$. and $14.8 \mathrm{mEq}$. per L., respectively, showed no urinary changes after the inhibitor when acidotic, but definite changes after correction of the acidosis with sodium citrate. Comparison of the individual values of this group with the other groups is diffcult owing to the effect of treatment superimposed on the basic urinary abnormality. Nevertheless, the increment in sodium and bicarbonate excretion after acetazoleamide is the same in magnitude in these three patients as in the patients in Group II.

\section{Group V-Ammonium chloride acidosis}

To determine more precisely the effect of acidosis alone without renal disease in conditioning the response to acetazoleamide, the two normal subjects M. K. and J. B. each ingested $374 \mathrm{mM}$ of ammonium chloride in gelatin capsules. This was taken in evenly divided amounts from 9 a.m. to 10.30 p.m. the day before taking acetazoleamide. The plasma bicarbonate at the end of the control periods was reduced to one-half of the value found the previous day before taking ammonium chloride. In both instances, there was partial blocking of acetazoleamide effect as indicated by absence of the customary sodium and bicarbonate diuresis. The change in the rate of ammonia and titratable acid excretion was probably due to withdrawal of the acid load rather than to acetazoleamide.

A further experiment was performed in which an attempt was made to keep the intracellular $\mathrm{pH}$ normal whilst at the same time creating an extracellular acidosis. M. K. ingested $336 \mathrm{mM}$ of ammonium chloride and $111 \mathrm{mM}$ of potassium chloride under the same conditions as in the previous two experiments. There was no difference, however, in the effect of acetazoleamide. Similar depression of serum bicarbonate was produced in both instances and with the supplementary potassium, the serum potassium rose from $3.93 \mathrm{mEq}$. per L. to $6.51 \mathrm{mEq}$. per $\mathrm{L}$.

\section{DISCUSSION}

The demonstration that metabolic acidosis blocks the effect of oral acetazoleamide in man is in complete agreement with the findings of Maren and Wadsworth in dogs (10). Reports of other workers stating that acetazoleamide exerts its customary action in metabolic acidosis $(1,11)$ are probably explained by the mild degree of acidosis in these experiments. From the present data, the blocking effect of metabolic acidosis was demonstrated in patients with renal disease when the plasma bicarbonate was $19 \mathrm{mEq}$. per L., or below. In the normal controls, this effect was observed when the plasma bicarbonate was in the neighbourhood of $16 \mathrm{mEq}$. per L.

Several possible mechanisms may be considered to explain the apparent lack of effect of acetazoleamide in metabolic acidosis. Impaired absorption of the drug is unlikely as it is known in the dog to be well absorbed from the gastro-intestinal tract with production of adequate blood levels even in the presence of metabolic acidosis (9). Also, in ammonium chloride acidosis in the dog, the effect of acetazoleamide is still blocked after intravenous administration (12).

No change in the pharmacological activity of acetazoleamide occurs within the intracellular $\mathrm{pH}$ range compatible with life (12). Furthermore, any change in the activity of carbonic anhydrase within this $\mathrm{pH}$ range is minimal (13). If an increased activity or amount of enzyme is assumed, then increasing the dose of inhibitor sufficiently would be expected to produce the usual urinary changes. However, even with doses as large as $100 \mathrm{mg}$. per $\mathrm{kg}$. in the dog, only 20 per cent of the expected bicarbonate excretion occurs in the presence of ammonium chloride acidosis (12).

It has been shown that the majority of the filtered base bound to bicarbonate is reabsorbed by a process of ion exchange with hydrogen ions secreted by the tubule $(14,15)$. The number of hydrogen ions secreted at any time, other things being constant, presumably depends on their availability within the tubular cell. The major contribution to this supply will be from the hydration of 
carbon dioxide, catalyzed by carbonic anhydrase as shown by the reaction

$$
\begin{aligned}
\mathrm{CO}_{2}+\mathrm{H}_{2} \mathrm{O} \stackrel{\text { C.A. }}{\rightleftarrows} \mathrm{H}_{2} \mathrm{CO}_{2} \\
\mathrm{H}_{2} \mathrm{CO}_{3} \rightleftarrows \mathrm{H}^{+}+\mathrm{HCO}_{3}-.
\end{aligned}
$$

If the concentration of hydrogen ions within the cell was increased secondary to changes in the extracellular fluid $\mathrm{pH}$, then it would be expected that proportionally less of the secreted hydrogen ions would originate through the action of carbonic anhydrase. Inhibition of the enzyme with acetazoleamide might then have less effect on base reabsorption than usual.

Conversely, decreasing the intracellular hydrogen ion concentration by infusion of sodium bicarbonate would make the enzymatic hydration process the principal source of hydrogen ions. Inhibition of the enzyme under these circumstances indicates that a larger than usual amount of bicarbonate escapes reabsorption $(16,17)$.

Leaf, Schwartz, and Relman (18) have suggested that with reduction in the filtered load of bicarbonate, fewer hydrogen ions are required for adequate base reabsorption. Less response might therefore be seen after carbonic anhydrase inhibition. This does not explain the absence of acetazoleamide effect in ammonium chloride acidosis where high rates of hydrogen ion secretion are found.

With reduction in renal mass by disease, a decrease in the carbonic anhydrase content of the kidney would be expected. Enzyme inhibition might then cause smaller urinary changes as compared with the changes produced in normal controls. The smaller increment in sodium and bicarbonate excretion in the patients with renal disease without acidosis is compatible with this. However, the changes in urine volume, $\mathrm{pH}$, potassium, ammonia, and titratable acid were not statistically different from the controls. This may be due to the small size of each group. It is also possible that although hydrogen ion secretion was effectively blocked, other tubular mechanisms ensured less sodium excretion than usual. In regard to this, the increased exchange of potassium for sodium is of interest and has been noted previously $(19,20)$.

In the patients with acidosis, the absence of any urinary changes after using acetazoleamide could be caused both by the acidosis itself and in addition by the other mechanisms discussed above.

The syndrome of idiopathic renal tubular acidosis has been suggested as being due to a deficiency of carbonic anhydrase in the renal tubules $(1,21)$. The excretion of an alkaline urine containing large amounts of base is similar to the urines produced after administration of acetazoleamide. In the three cases in this series, all showed evidence of functioning renal carbonic anhydrase. This suggests that some other metabolic abnormality, perhaps involving the transport of hydrogen ions rather than their production is at fault in this condition.

Except for transitory drowsiness and occasional headache, no side effects were observed in these patients. Even in those with advanced renal failure, no evidence of untoward effect was seen in the urine, blood pressure, or degree of azotemia, after the use of acetazoleamide. In view of the relative freedom from toxic manifestations to date, the drug might be considered as an adjunct in the treatment of patients with primary renal disease, or in other conditions complicated by renal disease where fluid retention exists. It might also be of value when alkalinization of the urine, or potassium loss is desired. The presence of azotemia, hypertension, or marked reduction in functional tests do not themselves contraindicate the use of the drug. However, if there is acidosis with a plasma bicarbonate below $19 \mathrm{mEq}$. per $\mathrm{L}$. then there will be no effect from its administration. A further limiting factor in the use of acetazoleamide as a diuretic in renal disease is the smaller increment in sodium excretion as compared to that found in normal people. It does not seem possible to predict beforehand the magnitude of this loss because of the large individual variation.

\section{SUMMARY}

The effect of a single oral dose of the carbonic anhydrase inhibitor, acetazoleamide, was studied in fifteen patients with renal disease and four normal controls. In the normal subjects, there was an increase in urine volume, rise in urine $\mathrm{pH}$, with sodium, potassium and bicarbonate diuresis. This effect was also produced in patients with renal disease without acidosis, but was smaller in magnitude. In the patients with renal disease and 
metabolic acidosis however, the urinary changes were minimal or absent completely.

Following production of ammonium chloride acidosis in two normal subjects, acetazoleamide failed to produce the customary urinary changes.

The reason for these findings and the possible therapeutic value of acetazoleamide in renal disease was discussed.

\section{ACKNOWLEDGMENTS}

I wish to thank Drs. J. S. L. Browne and L. G. Johnson for encouragement and advice during this investigation. Also Mrs. Shirley Bertram for charting the graphs, Miss Barbara Emmett and Miss Zina Malevitch and their assistants for technical help.

I am also indebted to the staff of the Children's Memorial Hospital, Montreal, for permission to study patient C. B. and to all those physicians who allowed access to their cases at the Royal Victoria Hospital. Finally, I would like to thank Dr. J. Bethune for acting as an experimental subject.

\section{APPENDIX}

\section{Group II}

J. S. 54-4008. Female, aged 39 years. Weight 70.0 kg. Hypertension discovered March 1954, blood pressure 240/140. Marked retinal changes with papilledema. Urinalysis showed protein +++ , with red and white cells and casts. Culture was sterile. Retrograde pyelography was normal. Tested with $687 \mathrm{mg}$. acetazoleamide on April 17th, 1954. The non-protein nitrogen was $46 \mathrm{mg}$. per cent, phenolsulfonphthalein excretion (P.S.P.) 37 per cent at 60 minutes and range of urine specific gravity 1003 to 1021 at this time.

F. S. 53-19228. Male, aged 50 years. Weight $75 \mathrm{~kg}$. Hypertension since 1940 at which time blood pressure $180 / 110$, rising to $250 / 150$ in 1953 . Investigation in 1950 showed the urine to contain protein + intermittently, with a few white cells. P.S.P. excretion was 37 per cent in 30 minutes and the urine specific gravity was 1023 after a concentration test. The serum non-protein nitrogen was $27 \mathrm{mg}$. per cent, and creatinine $1.2 \mathrm{mg}$. per cent. A pyelogram was abnormal on the left side and bacterial growth was obtained from both ureteral urines on culture. He was readmitted in 1953 when the urinary concentrating ability was reduced to 1015 , the 30 -minute P.S.P. was 15 per cent, the serum non-protein nitrogen 29 to $52 \mathrm{mg}$. per cent and creatinine $1.91 \mathrm{mg}$. per cent. Rice diet was started on December 10th, 1953, and he was tested with $750 \mathrm{mg}$. acetazoleamide on December 23rd. The non-protein nitrogen was $38 \mathrm{mg}$. per cent, P.S.P. 23 per cent, at 60 minutes and range of urine specific gravity 1002 to 1015 at this time.

F. St. 54-5293. Female, aged 45 years. Weight 50 kg. Diabetes mellitus was discovered in 1947. Subse- quent control was poor. In 1952, blood pressure $150 / 80$, the urine contained frequent white cells. Urine culture was sterile and the specific gravity was fixed between 1004 to 1010 . The non-protein nitrogen was $31 \mathrm{mg}$. per cent. In 1953, generalized edema developed with proteinuria ++ . Her condition was worse in 1954, edema was still present, blood pressure 160/90. The serum proteins were $6.55 \mathrm{gm}$. per cent, albumen $3.03 \mathrm{gm}$. per cent, globulin $3.52 \mathrm{gm}$. per cent, cholesterol $448 \mathrm{mg}$. per cent. Tested with $500 \mathrm{mg}$. acetazoleamide on April 14th, 1954. The non-protein nitrogen was $55 \mathrm{mg}$. per cent, P.S.P. 10 per cent at 60 minutes, and range of urine specific gravity 1001 to 1013 at this time.

L. D. 53-18500. Male, aged 11 years. Weight $37 \mathrm{~kg}$. Severe attack of acute nephritis in 1949 with apparent complete recovery. Readmitted on November 18th, 1953, with hematuria, proteinuria +++ and casts in the urine following a sore throat. Blood pressure was $110 / 64$, nonprotein nitrogen $80 \mathrm{mg}$. per cent, serum proteins $6.25 \mathrm{gm}$. per cent, albumen $2.5 \mathrm{gm}$. per cent and globulin $3.7 \mathrm{gm}$. per cent. Tested with $375 \mathrm{mg}$. acetazoleamide on November 25th, 1953. The non-protein nitrogen was $29 \mathrm{mg}$. per cent, and range of urine specific gravity 1003 to 1020 at this time. He was discharged clinically well on December 7th, 1954, but the urine still contained protein ++ and white cells.

R. G. 54-5394. Male, aged 21 years. Weight $77.2 \mathrm{~kg}$. Admitted on April 2nd, 1954, with acute nephritis. The blood pressure was initially $172 / 135$ and gradually fell to 130/85. Tested with $750 \mathrm{mg}$. acetazoleamide on April 28th, 1954. The non-protein nitrogen was $36 \mathrm{mg}$. per cent, P.S.P. 65 per cent at 60 minutes and range of urine specific gravity 1002 to 1014 at this time. He was discharged on May 17th, 1954, at which time the urine still contained a trace of protein and occasionally white cells.

T. W. 53-19849. Male, aged 4 years. Weight $20 \mathrm{~kg}$. Onset of generalized edema in September, 1953, with proteinuria ++++ , serum proteins of $4.51 \mathrm{gm}$. per cent, albumen $1.49 \mathrm{gm}$. per cent, globulin $3.02 \mathrm{gm}$. per cent, cholesterol $362 \mathrm{mg}$. per cent, and non-protein nitrogen 24 mg. per cent. Diuresis after receiving ACTH at this time. Readmitted on December 11th, 1953, with recurrence of edema, fever, and vomiting. Tested with 200 mg. acetazoleamide on December 16th. The non-protein nitrogen was $19 \mathrm{mg}$. per cent and range of urine specific gravity 1004 to 1030 at this time. Closed drainage of a large empyema was performed on December 22nd, and subsequently diuresis occurred.

\section{Group III}

R. Y. 53-4827. Female, aged 53 years. Weight 56.5 kg. Hypertension was discovered in 1945 and diabetes mellitus one year later. Blood pressure 196/108, proteinuria and diabetic retinopathy at this time. Onset of generalized edema in 1949, with proteinuria +++ , and white cells and casts in the urine. The serum proteins were $4.78 \mathrm{gm}$. per cent, albumen $3.33 \mathrm{gm}$. per cent, globulin $1.45 \mathrm{gm}$. per cent, non-protein nitrogen $62 \mathrm{mg}$. per cent, and cholesterol $385 \mathrm{mg}$. per cent at this time. Her 
condition was unchanged in 1954, but the non-protein nitrogen had risen to $107 \mathrm{mg}$. per cent. Tested with 562 mg. acetazoleamide on April 7th, 1954, when on $600 \mathrm{mg}$. sodium diet. The non-protein nitrogen was $110 \mathrm{mg}$. per cent, P.S.P. 5 per cent at 60 minutes and range of urine specific gravity 1005 to 1013 at this time. Developed a myocardial infarction and died on May 11th, 1954. Autopsy revealed advanced Kimmelstiel-Wilson lesions in the kidneys.

J. B. 54-3202. Male, aged 75 years. Weight $65 \mathrm{~kg}$. Admitted in uremia, urine contained protein ++ , and numerous red and white cells. Tested with $625 \mathrm{mg}$. acetazoleamide on March 10th, 1954. The non-protein nitrogen was $81 \mathrm{mg}$. per cent, P.S.P. 3.5 per cent at 60 minutes and range of urine specific gravity 1008 to 1012 at this time. Became jaundiced terminally and died on March 25th, 1954. Autopsy showed chronic pyelonephritis and post-necrotic hepatic cirrhosis.

M. A. 54-17891. Female, aged 14 years. Weight 37 kg. Neurogenic bladder with incontinence present since infancy. Urinalysis showed protein $t$, with frequent white cells. The hemoglobin was 50 per cent. Serum sodium $150.7 \mathrm{mEq}$. per L., potassium $5.29 \mathrm{mEq}$. per L., chloride $110 \mathrm{mEq}$. per L., bicarbonate 13 to $18 \mathrm{mEq}$. per L., calcium $3.4 \mathrm{mEq}$. per L., phosphorus $2.87 \mathrm{mEq}$. per L., and alkaline phosphatase 32.2 units. Urinary calcium was 0.7 to $2.3 \mathrm{mEq}$. per $24 \mathrm{hrs}$. on a $90 \mathrm{mEq}$. calcium intake. The urine $\mathrm{pH}$ fell to 6.1 only, after ammonium chloride, whilst the serum bicarbonate fell from 13.9 to $8.2 \mathrm{mEq}$. per L. Rachitic changes were present at all epiphyses radiologically. Tested with $375 \mathrm{mg}$. acetazoleamide on January 27 th, 1954, before any treatment. The non-protein nitrogen was $78 \mathrm{mg}$. per cent and range of urine specific gravity 1003 to 1012 at this time.

F. L. 54-1270. Male, aged 53 years. Weight $74 \mathrm{~kg}$. Urinalysis normal, blood pressure $104 / 58$ and non-protein nitrogen $42 \mathrm{mg}$. per cent in 1945. Admitted in uremia in 1954. The urine contained protein +++ , red and white cells and casts. Retrograde pyelography was normal. Tested with $750 \mathrm{mg}$. acetazoleamide on January 27th, 1954. The non-protein nitrogen was $111 \mathrm{mg}$. per cent, and range of urine specific gravity 1006 to 1016 at this time.

A. S. 54-456. Female, aged 46 years. Weight $50 \mathrm{~kg}$. Carcinoma of the cervix was diagnosed in 1952. Blood pressure $138 / 84$, urinalysis normal, non-protein nitrogen $22 \mathrm{mg}$. per cent and cystography and pyelography normal at this time. Received X-ray therapy. The carcinoma recurred in October, 1953, when complete obstruction of the left ureter with partial obstruction of the right ureter was demonstrated. The blood pressure was 160 / 100 and the non-protein nitrogen $22 \mathrm{mg}$. per cent. She was admitted with a subarachnoid hemorrhage and uremia on January 8th, 1954, and tested with $500 \mathrm{mg}$. acetazoleamide on January 20th, 1954. The non-protein nitrogen was $103 \mathrm{mg}$. per cent and range of urine specific gravity 1012 to 1017 at this time.

P. H. 54-1580. Female, aged 37 years. Weight $53 \mathrm{~kg}$. Admitted January 27th, 1954, in uremia. The blood pres- sure was $150 / 80$, urinalysis showed protein +++ , with numerous red and white cells and casts. Tested with 500 mg. acetazoleamide on February 3rd, 1954. The nonprotein nitrogen was $106 \mathrm{mg}$. per cent, P.S.P. 0 per cent at 60 minutes and range of urine specific gravity 1006 to 1012 at this time. Gradually deteriorated with rising blood pressure to 205/115 and died on April 27th, 1954. Autopsy showed chronic pyelonephritis, both kidneys weighing a total of $75 \mathrm{gm}$.

\section{Group IV}

C. B. C.M.H. 54-650. Male, aged 4 years. Weight $12.5 \mathrm{~kg}$. Episodes of fever and vomiting since infancy. One of these in February, 1953, was associated with tetany. Admitted on February 6th, 1954, with pneumonia and carpopedal spasm. History of polydipsia, polyuria, and a high milk intake. Examination showed him to be small for his age. Urinalysis showed occasional white cells, $\mathrm{pH} 6.1$ to 6.7 . Urea clearance was 44 per cent of normal. Serum sodium $145 \mathrm{mEq}$. per L., potassium 5.2 mEq. per L., chloride $103.5 \mathrm{mEq}$. per L., carbon dioxide content 16.3 to $22.0 \mathrm{mEq}$. per L., calcium $2.9 \mathrm{mEq}$. per $\mathrm{L}$. on admission and thereafter $4.9 \mathrm{mEq}$. per L., phosphorus $2.9 \mathrm{mEq}$. per $\mathrm{L}$., and alkaline phosphatase 2 units. Radiological examination revealed bilateral nephrocalcinosis. There was no evidence of bone disease. Tested with 125 mg. acetazoleamide on March 1st, 1954. The non-protein nitrogen was $28 \mathrm{mg}$. per cent and range of urine specific gravity 1001 to 1007 at this time.

M. B. 54-5719. Male, aged 16 years. Weight $25.6 \mathrm{~kg}$. Grew normally until aged 7 but had not grown since. Skeletal deformity was noted one year later. Examination showed him to be dwarfed with enlarged epiphyses. Blood pressure 118/50. Urinalysis negative. The urine $\mathrm{pH}$ was never below 7.0. Urea clearance was 28 per cent of normal. There was no amino aciduria. The serum proteins were $6.51 \mathrm{gm}$. per cent, sodium 141.5 mEq. per L., potassium $3.27 \mathrm{mEq}$. per L., chloride 114 mEq. per L., bicarbonate 12 to $15 \mathrm{mEq}$. per L., calcium $5.3 \mathrm{mEq}$. per L., phosphorus $1.36 \mathrm{mEq}$. per L., and alkaline phosphatase 106 units. There were marked rachitic changes at the epiphyses on radiological examination, and bilateral nephrocalcinosis was present. The excretion of titratable acid rose from $115 \mu \mathrm{Eq}$. per min. to 391 $\mu$ Eq. per min. with a fall in urine $\mathrm{pH}$ from 7.0 to 6.7 after infusion of neutral sodium phosphate. The serum phosphate rose from $1.45 \mathrm{mEq}$. per L. to $6.2 \mathrm{mEq}$. per L., and the urinary phosphate excretion from $20 \mu \mathrm{Eq}$. per min. to $167 \mu$ Eq. per min. Tested with $250 \mathrm{mg}$. acetazoleamide before and then after taking sodium citrate. The non-protein nitrogen was $30 \mathrm{mg}$. per cent, P.S.P. 58 per cent at 60 minutes and range of urine specific gravity 1000 to 1012 at this time.

F. P. 54-2220. Female, aged 29 years. Weight $38 \mathrm{~kg}$. She had passed urinary calculi since the age of 14 . Always taken a high calcium diet. Blood pressure 110/65, urinalysis showed protein + , with a few white cells. The urine $\mathrm{pH}$ was never below 6.9. Urea clearance was 30 per cent of normal. The serum proteins were 7.85 
gm. per cent, sodium $138 \mathrm{mEq}$. per L., potassium 3.13 mEq. per L., chloride $115 \mathrm{mEq}$. per L., bicarbonate 12 to $14 \mathrm{mEq}$. per L., calcium $4.9 \mathrm{mEq}$. per L., phosphorus $1.68 \mathrm{mEq}$. per L., and alkaline phosphatase 6.1 units. Radiological examination showed very advanced bilateral nephrocalcinosis but there was no evidence of bone disease. Tested with $375 \mathrm{mg}$. acetazoleamide before, and then after three months on sodium citrate. The nonprotein nitrogen was $26 \mathrm{mg}$. per cent, P.S.P. 19 per cent at 60 minutes and range of urine specific gravity 1005 to 1010 at this time.

\section{REFERENCES}

1. Berliner, R. W., Kennedy, T. J., Jr., and Orloff, J., Relationship between acidification of the urine and potassium metabolism. Effect of carbonic anhydrase inhibition on potassium excretion. Am. J. Med., 1951, 11, 274.

2. Friedberg, C. K., Halpern, M., and Taymor, R., The effect of intravenously administered 6063, the carbonic anhydrase inhibitor, 2-acetylamino-1,3,4-thiadiazole-5-sulfonamide on fluid and electrolytes in normal subjects and patients with congestive heart failure. J. Clin. Invest., 1952, 31, 1074.

3. Metcoff, J., James, J. A., and Gordillo, G., Observations on renal cellular electrolyte transport systems in normal and nephrotic children. J. Clin. Invest., 1953, 32, 590.

4. Van Slyke, D. D., and Cullen, G. E., Studies of acidosis. I. The bicarbonate concentration of the blood plasma; its significance, and its determination as a measure of acidosis. J. Biol. Chem., 1917, 30, 289.

5. Wilson, D. W., and Ball, E. G., A study of the estimation of chloride in blood and serum. J. Biol. Chem., 1928, 79, 221.

6. Fiske, C. H., and Subbarow, Y., The colorimetric determination of phosphorus. J. Biol. Chem., 1925, $66,375$.

7. Henderson, L. J., and Palmer, W. W., On the several factors of acid excretion. J. Biol. Chem., 1914, 17, 305.

8. Van Slyke, D. D., and Cullen, G. E., The determination of urea by the urease method. J. Biol. Chem., $1916,24,117$.
9. Maren, T. H., Pharmacological and renal effects of Diamox, (6063), a new carbonic anhydrase inhibitor. Tr. New York Acad. Sc., 1952, 15, 53.

10. Maren, T. H., and Wadsworth, B. C., Blocking of renal effect of Diamox 2-acetylamino-1,3,4-thiadiazole-5-sulfonamide by metabolic acidosis. Federation Proc., 1954, 13, 383.

11. Welt, L. G., Young, D. T., Thorup, O. A., Jr., and Burnett, C. H., Renal tubular phenomena under the influence of a carbonic anhydrase inhibitor. Am. J. Med., 1954, 16, 612.

12. Maren, T. H., Personal communication.

13. Roughton, F. J. W., and Booth, V. H., The effect of substrate concentration, $\mathrm{pH}$ and other factors upon the activity of carbonic anhydrase. Biochem. J., 1946, 40, 319.

14. Schwartz, W. B., and Relman, A. S., The dependence of renal sodium reabsorption on hydrogen exchange. J. Clin. Invest., 1954, 33, 965.

15. Dorman, P. J., Sullivan, W. J., and Pitts, R. F., The renal response to acute respiratory acidosis. $\mathrm{J}$. Clin. Invest., 1954, 33, 82.

16. Tudvad, F., McNamara, H., and Barnett, H. L., Renal response of premature infants to administration of bicarbonate and potassium. Pediatrics, 1954, 13, 4.

17. Schwartz, W. B., Danzig, L. E., and Relman, A. S., Role of carbonic anhydrase in renal tubular reabsorption of bicarbonate. Am. J. Med., 1953, 14, 526.

18. Leaf, A., Schwartz, W. B., and Relman, A. S., Oral administration of a potent carbonic anhydrase inhibitor ("Diamox"). 1. Changes in electrolyte and acid-base balance. New England J. Med., 1954, 250, 759.

19. Metcoff, J., and Wallace, W. M., The nephrotic syndrome in children: Response to intravenous sodium loads. J. Clin. Invest., 1950, 29, 835.

20. Burnett, C. H., Burrows, B. A., and Commons, R. R., The lack of correlation between glomerular filtration rate, and serum electrolyte concentration changes, urinary electrolyte excretion, or edema formation following sodium loads in subjects with normal kidneys, glomerulonephritis, and the nephrotic syndrome. J. Clin. Invest., 1949, 28, 773.

21. Israels, S., Delory, G. E., and Gourley, B., Induced renal hyperchloraemic acidosis. Pediatrics, 1954, 13, 64 . 